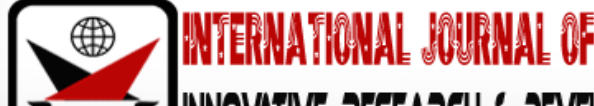

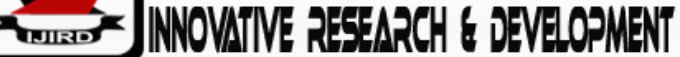

ISSN 2278-0211 (Online)

\section{Participatory Project Planning and Performance of Mango Farming Projects in Makueni County, Kenya}

Charles KyaleKisumbi
Ph.D. Candidate, Department of Management Science and Project,
University of Nairobi, Kenya
Dr. Angeline Sabina Mulwa
Senior Lecturer, Department of Educational Management, Policy and Curriculum Studies,
University of Nairobi, Kenya
Dr. John MwauraMbugua
Senior Lecturer, Department of Educational Management, Policy and Curriculum Studies,
University of Nairobi, Kenya

\section{Abstract:}

The purpose of this article is to create awareness of the need for a robust mango policy and practice paradigm shift from traditional planning methods to participatory project planning, to enhance performance. It is based on an empirical scientific research for PhD thesis carried out in Makueni County Kenya, focusing on the influence of participatory project planning and performance of mango farming projects. Project Management theory formed the basis that guided the study, descriptive cross-sectional study design was used whilepragmatism research paradigm which uses mixed method approach was adopted. A sample of 375 respondents was selected from a population of 12,622 mango farmers using multistage sampling technique. Data was collected using both self-administered questionnaires and interview of 15 key informants. Both descriptive and inferential data analysis techniques were applied. Null hypothesis which stated that, there is no significant relationship between participatory project planning and performance of mango farming projects was tested through F-test and correlation. The findings showed that there existed a statistically significant correlation between the two variables at $95 \%$ confident levels with $D f(2,367), F=2.402, t=1.469, p=0.000<0.05, r=0.339$ and $R^{2}=0.115$. It was concluded that there was significant relationship between participatory project planning and performance of mango farming projects and the null hypothesis was rejected since it was not supported by the results. Based on the findings this article recommends that, in order to improve performance, participatory project planning considerations supported by an appropriate iterative combination of planning measures which are inherent along the project management life cycle.Participatory project planning should always be embraced in crafting of policy for optimal practice directions, to enhance performance.

Keywords: Participatory project planning, project management life cycle, performance of mango projects, policy formulation and practice

\section{Introduction}

The Study examined the influence of participatory project planning and performance of mango farming projects in Makueni County Kenya. The study also sought to establish the extent to which moderating influence of Environmental Factors and its relationships between participatory project planning and performance of mango farming projects. Mango fruit, which is the basis of this study, is basically grown in Makueni County for households' consumption, trade to increase income and as a means of unlocking other socio-economic development opportunities that improve on living standards. Mango farming projects are part and parcel of wider agricultural projects, as depicted in the case of FARM Africa funding mango improvement projects at the Kenyan Coastal region, to reduce extreme poverty levels (KARI, 2008). A study on mango value addition on group projects (Mbithe, 2012), alluded to such a need of mango implementing effective farming projects in Makueni County to reduce extreme poverty levels rife in rural setups. All mango farming projects in Makueni were planned and implemented on similar circumstances to mitigate and intervene on eradicating or alleviating the severity of pervasive poverty levels. In Haiti for instance, which is a developing country, mango production was taken up as an economic paradigm shift and as an opportunity for long-term economic growth and development, funded with the help 
of Inter-American Development Bank Multilateral Investment Fund (MIF, 2010). Mangoes can become a feasible economic pillar as it is a huge economic pillar of Konkan Region of Maharashtra which drives economic growth and development in mango growing rural communities in India (Burondkar, Kulkarni, Salvi, Patil, Narangalkar, Joshi, Talathi, Naik, Malave, Bhosale, Deorukhakar, Bagade, Patil, Rane, Dodake, Haldankar and Bhattacharyya, 2018).

Although Makueni County became Kenya's top producer of mangoes, extemporaneous challenges emerged which needed to be addressed to improve to put mango performance on track. The goal of mango projects is to contribute in improving income growth opportunities for smallholder farmers and other participating meso-actors in the whole mango value addition chain. The primary benefit trickles down to the mango farmers, including processing and trading firms that spur sustainable mango performance (MIF, 2010). A study on small-scale production of agricultural projects in South Africa of stone fruits of peaches, apricots and nectarines showed that, the stone fruit projects failed due to lack of involving the real participatory actions of the fruit meso-actors (Hart, Burgess and Hart, 2005).Ibid,consequently, this affected the overall stone fruit production acumen, leading to poorly planned fruits projects that had shown to have continued in a project cycle life of their own, without following any clear project framework and direction to achieve the desired project outcomes to spur performance (Hart et al, 2005).

Poverty levels prevailing in the developing countries, especially in ASALs, can be reduced drastically to manageable levels through mango production since mangoes greatly supplement farmers' incomes and thrive well in hot temperate climatic conditions. Widespread poverties in Makueni mango zones are yet to be reduced to manageable levels, since they have remained among the highest in Kenya standing at (64\%), when compared to the national absolute poverty level of 47\% (MoALF, 2016). Even with multiplicity of concerted effort and multifaceted agricultural project approaches by national and county governments in combating pervasive poverty, poverty levels slightly dropped to 60.6\%, meaning it was still very high in the entire Makueni County (KNBS, 2019). Meaningful economic ways of eradicating poverty levels have remained a mirage to grapple with for a long time, yet mango farms are seen teeming with many mango trees all over the county. A study on postharvest of mango farmers' choice of marketing channels revealed that mango farming projects were introduced in Makueni County to help in mitigating extreme poverties, brought about by the adverse effects of frequent droughts, rampant food shortages, unending food insecurity, occasioned by declining agricultural potential of most staple food crops (Muthini, 2015). A Report on India's mango production for global markets was shown to have had attained a global sustainable performance in becoming a key driver for rural economic growth and development (Burondkaret al, 2018). Mangoes, just like other crop husbandry subsistence foodstuffs are cultivated for sustenance, mitigation of poverty and hunger, food security measures, employment and income generation endeavours in rural areas. Distinctive agricultural pathways stated in the 2030 UN's 17 SDGs provided diverse ways of achieving lasting food security solutions, mostly experienced in developing countries where security is still dire (FA0, 2017).

On the global scene and in the African context, the emerging trends of transitive agriculturally-based economies calls for improved agriculturally-based project planning innovative measures, which should be strategically fit, so that they able to intervene and mitigate on the pervasive food insecurity. Well planned agricultural projects could offer food insecurity solutions, if primarily influenced the existential foundation of development in the turning of the fundamental wheel of human needs scale development, in the midst of dualistic economic disparities which are predominantly rife in developing nations (Max-Neef, 1991). In order to achieve a wholesomedevelopment latitude, this could be the fundamental prerequisite practice and policy of transforming the traditional agrarian societies to actualize their modernization processes, along the incremental stages of economic expansion path, to economically 'induce' and spur the developmental stages of economic growth (Rostow, 1960). This view, to a great extent is collaborated in a study which found out that, economic development structures had a direct significant influence on governments' stimulus on economic growth through capital establishment (Rumawir, 2019). In his human needs scale development, Manfred Max-Neef alluded that, limitations to development were brought about by scarcity of resources which are essential for turning the fundamental wheel of socio-economic development to alleviate 'poverty pathologies', felt most in rural populations in developing countries (MaxNeef, 1991).

Discrepancies in supply and demand on mango production and markets occurred due to concurrence of vicious uncertain issues that recur in the whole mango chain from year to year. Lack of proper planning in adopting good project management practices in mango production and lack of establishing robust mango cooperative trade movements predisposed mango production to losses which eventually affected performance (Ravishankar and Misra, 2010). In order to improve and increase mango production, indigenous mango tree rootstocks needed to be grafted to new cultivars and saplings to create new prolific cultigens not prone or susceptible to diseases and pests infestation. Through robust iterative planning endeavours, new breeds of mango varieties could be propagated to discover new prolific mango varieties which would be more resistant to frequent looming droughts and less prone to the effects of variability of climatic changes and global warming. In this, it behoves Makueni county agriculturists to research on new mango breeds that more resistant to drought, diseases and pest infestations. Most of mango varieties, if not all, are exotic propagated breeds which face similarity market challenges. In order to compete favourably in global markets, Makueni County should have its own researched indigenous mango varieties adapted fully to the local climate.

The idea of developing new mango varieties envisaged a continued improvement in mango production, which in turn would enhance performance of mangoes with higher prolificacy rate. The world has seen subsistence agriculture transformed and revolutionized through technology to increase mango production. This is why majority of mango trees flourishing and flowering in tropical regions amazingly have had many years of life longevity, but are still producing mango fruits to date (PIM, 2018). Participatory project planning for implementation of sound mango projects can improve performance to spur mango socio-economic growth and development. It is apparent therefore, that mere planting of mangoes for local and global markets is no longer enough to warrant income and bumper harvests since more is needed in 
planning to improve performance. There as been erratic changes in global market environment which also affects managerial production aspects of mango farming projects. Participatory meso-actors in mango farming projects consists of individual farmers, mango buyers and sellers, government agricultural extension, global development partners, NGOs, agribusinesses and agricultural research stations, among others. These stakeholders endowed are with knowledge and technical skills able to drive mango performance in the right direction. There is need for concerted effort in planning to promote production in agriculture to improve sustainable food security and performance (Tesfaye, 2015).

Kenya's continued infrastructural development was envisaged to drive the country to a middle-economy status by 2030 (Kenya Vision 2030, 2008), which still may be on course in economic terms. Likewise and in the same direction, the global achievements to be attained, envisaged similar global economic trends on the developmental steady-state of nature's physiocratic invisible economic-hand, which is essential for growth along the economic expansion path as advanced in Harold-Domar economic model, among many others (Thong and Nguyen, 2019). Economic development and global partnerships puts more emphasis on UN 17 Sustainable Development Goals (SDGs), especially Goals 1 and 2, which deals with eradication of extreme poverty and hunger afflicting approximately one billion people globally (UN, 2015). The developmental taxonomy ideas visualized in the fundamental wheel of human needs scale development was rooted in rural community 'satisfiers' to identify 'wealths' and 'poverties' through self-reliance planning with autonomy by people and governments, so as to eradicate pervasive extreme poverties felt most in the decade of 1980semphasised in the Latin American Economic Crisis and Perplexities (Max-Neef, 1991). Planning concerns determining in advance of what needs to be done before implementation, and therefore, without planning, one has already unintentionally planned to fail. This makes the project planning phase paramount when enhancing mango performance.

\subsection{Purpose of the Study}

The purpose of the study was to investigate the influence of the participatory project planning and performance of mango farming projects in Makueni County Kenya.

\subsection{Research Objective of the Study}

The research objective of the study was to determine how participatory project planning influenced performance of mango farming projects in Makueni county Kenya.

\subsection{Research Hypothesis Testing}

In this study, the following research hypothesis (null) was tested:

- $\mathrm{H}_{0}$ : There is no significant relationship between participatory project planning and performance of mango farming projects in Makueni County Kenya.

- Alternative hypothesis:

- $\mathrm{H}_{1}$ : There is a significant relationship between participatory project planning and performance of mango farming projects in Makueni County Kenya.

\subsection{Significance of the Study}

The findings of the study were envisaged to offer tangible empirical evidence on Participatory Project Planning inenhancing Performance of Mango Farming Projects in Makueni County. The findings found out that the Mango tree is a key fundamental intervention project which can improve household income through robust participatory project planning as taught in the discipline of project planning and management. It anticipated to expand the existential steady-path of micro-economic growth factors, essential for driving the wheels socio-economic development in order to alleviate or eradicate the prevailing pervasive poverty levels, currently standing at $60.60 \%$ (KNBS, 2019). There were many mango meso-actors involved in mango value chain such as Makueni County Government, agricultural extension officers, mango micro-financing firms, and buyers, companies processing mango juices, various traders and exporters. Mango production can be improved significantly in collaboration with various mango stakeholders to check on the dearth of infrastructure and other institutional economic deficiencies experienced in the whole mango chain (Purushottam, 2015). The provided valuable information to various mango stakeholders, who will use the information to offer solutions to myriads of problems experienced in the whole mango value chain for practice and policy formulation.

The Mango fruit is a key contributor to the county's economic growth and socio-economic development in enhancing mango farmers' better living standards. Mango farming just like other cultivated foodstuffs, it is fundamental to achieving the Vision 2030 pillars driven by economic, political and social dimensions envisaged to make Kenya a middle economy earner (Kenya Vision 2030, 2008). The mango fruit takes time to mature from planting to harvest and can take between 4 to 7 years before the first harvest. This depends on the cultivars' types of mango indigenous trees, grafted mango trees, the quality of scion saplings and rootstocks available to the farmers during planting time. Mango production is important for enhancing socio-economic development, essential in vouching for satisficing strategies that offer pragmatic effort to improve people living standards. In spite of many long years of waiting, with unrecoverable hidden sunk costs, a lot could be achieved and quantified starting from pre-harvest planning of planting materials to postharvest stages to appraise numerically the 'steady-state' economic path for enhanced mango performance.

\subsection{Statement of the Problem}

The evolution of mango farming projects in Makueni commenced almost instantaneously due to the rising need for improving the indigenous mango varieties in the face of dwindling agricultural production, erratic rainfall patterns and looming pervasive poverty levels. Although Makueni County, over time became leader in mango production in Kenya, new 
mango challenges emerged affecting overall mango performance in many farms. The challenges were experienced along the preharvest and postharvest phases due to lack of incorporating participatory project planning iterative activities to enhance performance. Mango diseases and pests' infestations did not seem to go way, thus affecting production, marketing and pricing of mangoes in the whole mango chain. Planning is paramount in checking failure of project performance. With the advent of Mango farming projects, seen in the same way as in FARM Africa funding mango improvement projects at the Kenyan Coastal region, were deemed to be feasible and viable for reducing extreme poverty and unlocking social-economic opportunities, including value addition (KARI, 2008; Mbithe, 2012). This notwithstanding, the local and global mango agribusiness awareness on alternative income generation, coupled with conducive climate for mango production, led to an exponential influx of more prolific exotic mango varieties in Makueni County. Mango fruit is a major socio-economic player in developing countries for providence of food sustenance, employment, essential jump-starting agro-industrial revolution to induce economically inspurring economic growth and development. However, there were numerous emerging impediments in spite of the mango fruit's increased production (Korir, Mutwiwa, Kituu and Sila, 2017). It has been reported further that a range $40-45 \%$ of mangoes were usually lost annually due postharvest handling challenges (Ambuko, 2019; Korir et al, 2017). In order to improve performance, planning is a key component (Storrs, 1949). In study on mangoes postharvest, it was reported that mango cultivation was riddled with many problems (Muthini, 2015).

Improved mango performance can only beachieved by implementing feasible and viable mango farming projects, along the preharvest to postharvest stages. In mango production, quality of mangoes can only be improved along the preharvest phases and definitely not in the later postharvest stages when damage has already been done.Middle-men menace was pointed out as one of the stumbling blocks in low pricing of mangoes besides dismal functioning of the respective nodal institutions concerned (Purushottam, 2015;Muthini, 2015)Nevertheless, better performance in mango production in quantity and quality can only be improved and maintained at preharvest production level, since it cannot be improved later along postharvest stages (Mathieu and Joas, 2007).Mango failure should be blamed on poor project planning. Mangoes wasted are not something new in Makueni, since most mango losses occurred along the preharvest spilling over into the postharvest stages. Unplanned preharvest factors influences postharvest pests such as mango fruit fly, besides other various diseases infesting mangoes, consequently affecting fruit quantity and quality in the overall performance (Rehmanet al, 2015). Mango production in Makueni was affected by lack of well-planned mango policies, lack of involving expert support in planning, besides the effects of other emerging Socio-economic trends, funding, climate variability and middlemen menace offering low prices that did not even break-even on cost of production (Muthini, 2015; Purushottam, 2015; Choudharyet al, 2015). There were no serious mango marketing cooperative movements to offer modern production methods, leading to problems of collective bargaining in local and global markets. Further contemporary emerging issues raised were lack of mango skills, inadequate storage facilities, disorganized mango collection points, preharvest and postharvest losses(PHL)which ranged between 40 to 45 percent and reduced yields, thus affecting performance (Osena, 2011).

A study on mango postharvest challenges in Makueni County, recommended for a further research to be undertaken on 'opportunities and constraints' faced in mango production (Muthini, 2015).There were losses experienced in wilting and falling small unripe mangoes in preharvest mango production phases which spilled over as postharvest (PHL) losses, compounding production problems. Various studies have revealed that mango production was riddled with many problems of mangoes being prone and susceptible to numerous pests and diseases infestations, which accounted for 45\% of mango postharvest losses, PHL (Ambuko, 2019; UN women, 2018; Koriret al, 2017; Muthini, 2015). It has been pointed out further that, limited access to good planting materials, devastating preharvest pests and diseases, postharvest losses, poor orchard management led to low returns, which affected mango performance in the long run (Oxfam, 2019).Mango statistics revealed a fluctuating and declining performance in the whole mango chain from preharvest and postharvest phases of production to market sales, year in, year out, for no apparent expert planning reasons. Performance of mangoes has seen yearly deferential declines and fluctuations in South-East Asia which in heydays contributed $77 \%$ of all mangoes produced globally, with the Indian sub-continent leading with increasing at a decreasing rates of 54\%, 46\%, $40 \%, 47 \%$, whereby Kenya contributed $1.7 \%$ and $5 \%$ in total global mango production in different years (FSD Kenya 2015; HCDA, 2010; Tharanathan, Yashoda and Prabha 2006; Purushottam, 2015). It has also been revealed that 40-45\% of mangoes were lost in postharvest phase making declines and fluctuations from year to year due to poor planning methods(Ambuko, 2019; Korir et al, 2017). Owing to these drawbacks, mango performance could be enhanced through participatory project planning iterative activities that alleviate most project impediments that affect overall performance.

\section{Literature Review}

\subsection{Participatory Project Planning and Performance of Mango Farming Projects}

Planning is a key component of the modern discipline of project planning and management, paramount in enhancing project performance. Without planning, a project is bound to fail since planning entails determining in advance on what to be done before it happens. On developing project activation schedules therefore, when the baseline foundation has been achieved, project initiation phase precedes project planning, which is the $2^{\text {nd }}$ phase in project management life cycle, fundamental in planning for project's human and material resources. Planning is key to the overall performance of mango farming projects run by mango individual farmers including support from other intermediary mango mesoagencies. Project planning is the second phase of project management life cycle whereby, all the resources identified in project initiation are planned for implementation (Westland, 2008). Project planning is a la prévoyance case of a future foresight, looking forward to the optimal utilization of project resources just before the project implementation phase starts. Project planning comes first before all things and it is the best raison detretechnique for determining in advance on 
what is to do before it is done, in people-centred developmentprojects. Without proper project planning everything would fail to achieve the projected objectives and expected goals (Amadi, 2017; Storrs, 1949). For instance, a study in Benin revealed that mango farmers should always anticipate and plan for unknown eventualities and uncertainties that can affect mango farm ecosystems; as exemplified in 22 species of ants (Hymenoptera: Formicidae) fauna found in mangoproduction (Taylor, Norbert Sinzogan, Adandonon, Kouagou, Bello, Wargui, Anato, Ouagoussounon, Houngbo, Tchibozo, Todjihounde and Jean-François, 2018).

If a mango farmer does not plan, mango farming project plans are bound to fail in projected performance. Participatory project planning is able to influence the performance of mango farming projects in different environmental setups and situations. For instance, the planning role of arboreal Oecophyllalonginoda (weaver ants), being a key method of conservative biological control activities, as they can be used against mango fruit flies promoted to mango growers; with this knowledge of the ant fauna of the remarkably poor in Benin,could be compared with the other countries in the subSaharan Africa as a prerequisite for planning intervention (Taylor et al, 2018). Project planning plays a major role in having robust implemented projects that lead to improved mango performance. Project planning entails considerations of all project resources as put forth by Turner (1999), who alluded that a project involves delivery of beneficial change, in qualitative and in quantitative terms. In this case, Participatory project planning attempts to bring together all concerned mango stakeholders to improve performance. The planning element in the Fayol's managerial functions is a key component of general management which is supposed to determine in advance on what is to be accomplished as advocated in the general industrial management theory (Storrs, 1949; Fayol, 1916). The general management function should not be confused with project management, although it is critical in achieving the expected outcome in the project implementation and its eventual performance. Mango production is usually affected by lack of planning for resources due to project constraints, technological complexities, output fluctuations, besides the level of commercialization driven by low technological influence and unsustainable institutional support (Sulistyowati and Natawidjaja, 2016).

Participatory project planning for commercialization is a very significant process of transforming from subsistence toward commercial agriculture, to improve price competitiveness for increased income through education and awareness of healthy living on consumption of the mango fruit (Sulistyowati, et al, 2016). Involvement of key stakeholders in planning and implementing mango projects provides directional evaluation of processes that increase mango production. A study in a mango growing community indicated some mango growers had actively started to conduct proper cultivation techniques which applied new technology to change sales orientation towards internationally planned markets (Sulistyowatiet al, 2016). In project planning, monitoring and evaluation can be planned in advance on how it will be managed and executed in the identification of the most effective traps and lures that control mango stone weevil in mango orchards (Anderson, Tantoh, Akotsen-Mensah, Osei-Safo and AfrehNuamah, 2016). It behooves all the concerned stakeholders to agree on the best project planning processes that lead to proper utilization of scarce resources for combating mango rampant diseases and pests during preharvest and post-harvest phases. In developing countries, premature mangoes are usually affected by damaging pest infestations (Anderson et al, 2016). Individual mango farmers and other key mango actors including government extension officers, mango farmers could be empowered to improve mango production. Government's support in market planning, regulation and mango policy formulation and execution, is vital for continued collaboration between key stakeholders' participation, for improved planning for implementation (Mbeche et al, 2013; Aref, 2011). It is apparent that mangoes are prone and susceptible to various diseases and pests that need to be mitigated so as to increase mango production by individual farmers through sound planning procedures. Proper planning and monitoring and evaluation activities in mango farming is limited, thereby leaving several questions unanswered concerning the ecology and management practices of pests and diseases control measures (Anderson et al, 2016). Project planning is of major importance for future forecasting and understanding of mango production (Dessalegna, Habtemariam, Dersoc and Teferad, 2014). Even with advancement in managerial and technological skills, some challenges in mango farming are not yet known to this very day and recur from time to time (Dessalegnaet al, 2014).

World over, mango fruit production planning plays a significant role in being the source of raw materials for manufacturing industries, in providing employment to youth who make the majority of world's growing population. Low quality of mangoes, can be addressed through other key mango varietal diversity, which needs to be introduced to achieve higher mango production (Dessalegnaet al, 2014). It is important therefore, to plan and design mango farming projects that determine the expected production quantity and quality before implementation. Project planning designs should be thought of carefully so that the project plans are implementable without omitting details which force reviews of replanning at later stages of the project management life cycle. It is important to involve stakeholders since they are the ones who have the technological expertise and managerial technical knowhow of sustaining the projects to the very end when project managers exit the projects on plan completion. Furthermore, agriculture has been reported to be the most important sector for any country's economic growth and development, essential for alleviating pervasive poverty experienced in rural communities and hence the need of robust project planning (Aref, 2011). Project managers, project sponsors, agricultural extension officers and development partners should come together to participate with mango farmers since they are key national planners for robust food production. Project stakeholders are key drivers in planning for project appraisals and managerial procedures in mango orchards. Capacity building and planning in agricultural sector reduces youth unemployment, reactivates and re-awakens agriculture potentials in youth empowerment programmes, such as in mango farming (Latopa, Norazizan and Rashid, 2015). Through project planning, capacity building identifies and plans for strategic fit mango production procedures that achieve food sufficiency for national consumption and surplus for export to earn foreign exchange. It has been revealed that the youth have a lot of synergies that can be tapped early to sustain performance of agriculture projects, for a long time (Latopaet al, 2015). Nevertheless and on short timelines, even on attaining robust programmes, a lot of training and mentorship is required to stabilize performance of mango to spur 
socio-economic growth and development. In agriculture, there are inherent obstacles that affect agricultural empowerment programmes such as youth psychology, environmental factors,besides other farm input constraints (Latopaet al, 2015).

All projects require strong management skills to achieve successful planning and implementation. In their study (Pryor and Taneja, 2010), they found planning was a key component driving all managerial functions and the accompanying six organizational activities (technical, commercial, financial, security, accounting and management). Planning is futuristic in nature as well as forward looking in sense that, it aims at achieving the envisaged realities in projects before anything is done at all. It was also revealed that, there were many critics who reviled Fayol and disparaged his classical management functions and his 14 principles of management, but even so, he still had many scholarly followers who respected and revered him with same measure, on his general management planning concept that changed the world of development projects (Pryor et al, 2010).In his management functions process, Henri Fayol proposed 14 principles of management consisting of Division of Work, Authority, Discipline, Unity of Command, Unity of Direction, Subordination of Individual Interests, Remuneration, Centralization/decentralization, Scalar Chain, Order, Equity, Stability of Tenure, Initiative, Esprit de Corps, which promoted teamwork spirit and unity, including institutional management through the six key organizational activities (Fayol, 1916; Storrs, 1949; Pryor et al, 2010). The Fayol's six key General Industrial Management activities are composed of the Technical, Commercial, Financial, Security, Accounting and Management activity consisting of five functions which includes planning (Fayol, 1916). Mango projects should always be planned with a sense of accuracy as advocated by Henri Fayol method of planning. The Fayol's general management, the $6^{\text {th }}$ activity is composed of prévoyance (Planning) forecasting in form of planning, organizing, staffing, directing/leading and controlling, which are considered to be the most important drivers of organizations in solving problems to achieve organizational goals and objectives (Fayol, 1916; Gulick et al, 1937;Pryor et al, 2010).

Planning is a managerial function which influences the raison detre main reason for existence of project organizations that meet societal expected needs in community and business obligations. In order to achieve robust success in developmental projects, the managerial function of planning should be interpolated with project managerial roles as postulated by Henry (Mintzberg, 1973). Projects organizations can achieve unprecedented success by incorporating the Mintzberg's ten Managerial Roles which comprises Interpersonal Roles, the figurehead, leader and liaison; Informational Roles, the monitor, disseminator and spokesperson, and Decisional Roles, the entrepreneurship expertise, disturbance handler on conflicts, resources allocator and negotiator, since they are key drivers of projects' planning and implementation (Mintzberg, 1973). The management functions are thought to be the best approach in having creative ways of solving project organizations problems to spur socio-economic growth and development in far flung rural communities. The concept of planning in organizations by use POSDCORD analogy in managerial overview and planning, is a concept of project management, and is used today in the study of project planning and management (Agrawal and Vashistha, 2013). Over time, the planning concept has been concretized further and adopted in many disciplines including project planning and management to form project planning, the $2^{\text {nd }}$ phase in project management life cycle. Modern scholars and project managers have adopted planning as a futuristic prévoyance concept to address sound project planning iterative activity processes for individual and community projects. In any project, planning takes most of the $60 \%$ time more than all other the project iterative activities combined because many projects fail at the project planning phase or stage. The planning concept has also been addressed in the POSDCORD (planning, organising, and Staffing, directing, coordinating, reporting and budgeting) as revisited by (Gulick and Urwick, 1937; Pryor et al, 2010;Chalekian, 2013). Participatory project planning adopted in the study, is a key variable for finding its influence on the performance of mango farming projects in Makueni County, Kenya.

\subsection{Theoretical Framework}

The study made use of Project Management Theory, as it ubiquitously reinforced the planning concept and its bounding-assumptions in the project management life cycle (Warburton and Cioffi, 2014). A theory simply explains what the study phenomenon is and how it works within the theoretical framework, which is composed of such an important tool consisting of important basic features that are straightforward to the study (Torraco, 2004). On the forgoing, this study made of use other supporting theories, namely; Stakeholder Theory (Freeman, 1984), Ladder Citizen Participation (Arnstein, 1969), Theory of Constraints (Goldratt, 1990). The Citizen Participation Ladder Theory was relevant to the study as it vouched for empowerment techniques since planning is grounded in it as a "community-based planning process" which brings together various project stakeholders, the "powerful (government or other nodal entities)" and the "powerless (the community)", to participate amicably in planning of community development projects (Arnstein, 1969). The theory of constraints is important to study as it balances out mango project cost, time and scope, while stakeholder theory brings together various mango stakeholders to participate in mango production. The project management theory vouched for the study variable of participatory project planning.

\subsection{Conceptual Framework}

Conceptual framework is an explicit or implicit set of interrelated theoretical study concepts that show the underlying bounding confines and assumptions of the independent variable/s pointing to one dependent variable. It is also a complex formulation of knowledge, mental experiences interconnecting the theoretical framework theory on which the study is based; which basically entails conceptual framework being the operationalization of the theory into the study's dependent variable (Chinn and Kramer, 1999). In this, Conceptual Framework forms the heart of any study in being the very ultimate foundation of the study topic's; Research objectives, Research questions, Research Hypothesis, which thus dictates the direction of the literature review in forming the basis for pragmatism research paradigm in data collection techniques and data analysis tools and in the making of conclusions and recommendations, that impute generations and 
inferences to the whole study population (Chinn et al, 1999).The principle guiding concepts, that is, the independent variable/s to one dependent, must be interrelated and interlinked in the conceptual framework organized in a manner that makes them easy to communicate the relationships to the study phenomenon (Chinn et al, 1999). Thus, the conceptual framework is normally summarized in a schematic diagram labelled clearly to show the relationships between the independent variables and one dependent variable, including the exogenous/endogenous moderating variable. In any study, independent variables are the cause of outcomes whether significant, insignificant or otherwise in statistical measures; while the dependent variable is the phenomenon under study. The conceptual framework is conceptualized by digging deeper into literature review for the theoretical framework which is explained in words narrative form from the suitable theories, for conceptualizing the independent variables that will be used to measure quantitatively or qualitatively the one dependent variable (Chinn et al, 1999).

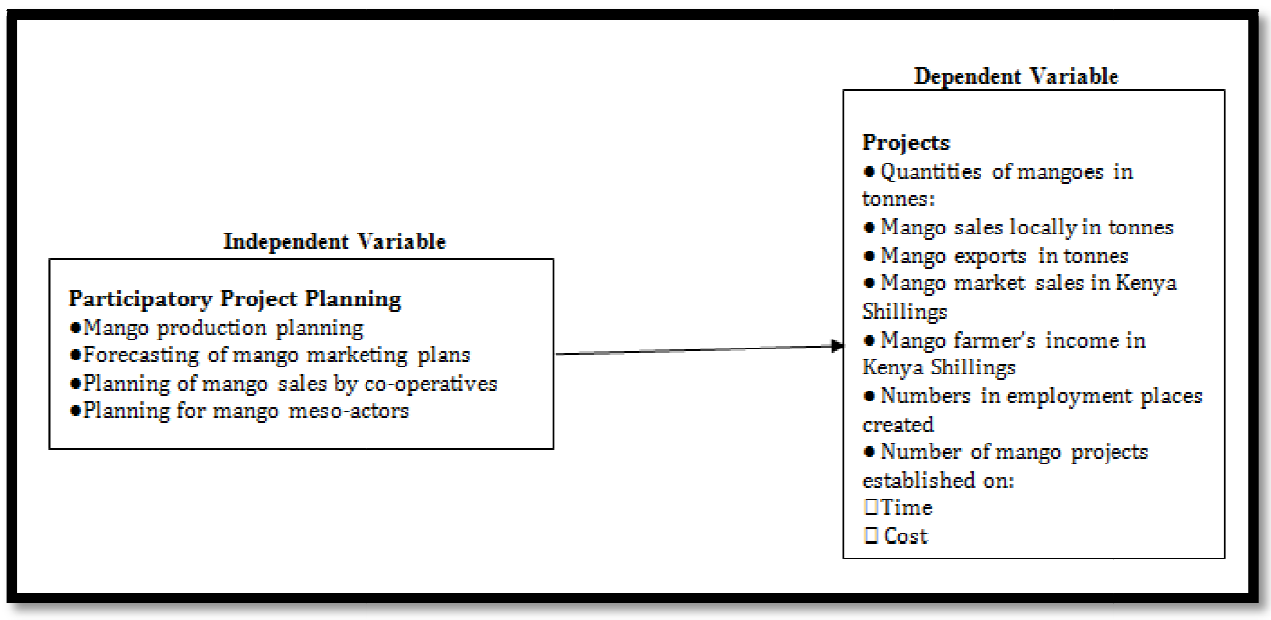

Figure 1: Conceptual Framework Diagram

Conceptual Framework for Participatory Project Planning and Performance of Mango Farming Projects in Makueni County, Kenya.

\section{Research Methodology}

\subsection{Research Paradigm}

Pragmatism research paradigm was used in the study as it allowed mixed method concurrent data collection and analysis in practical manner. The term Paradigm was originally coined for use in scientific research, from where it gained a scholarly momentum over time and further proposed and redefined as an effective worldview for guiding researchers to focus on one certain direction in a particular area (Kuhn, 1962).From this worldview therefore, pragmatism research paradigm combines positivism quantitative view and interpretivism or post-positivism view towards the ontological phenomenon under study. The principles of pragmatism research paradigm are based on the propositions that, researchers should use the philosophical and/or methodological approach that works best for a particular research problem statement, being investigated in an empirical way (Tashakkori and Teddlie, 1998).

\subsection{Research Design}

A research design is a structured blueprint or roadmap plan for conducting scientific research to answer the fundamental research problem. This study made use of a descriptive cross-sectional survey and correlational research designs. The descriptive cross-sectional survey it is a scientific plan for studying empirically the research problem involving collection of data by questionnaires, interviews and observations in order to learn people's beliefs or opinions at one point in time (Neuman, 2007). The correlational research design was important as it involved the measuring of two or more variables, independent and dependent, without the control of the researcher. The scientific purpose of this was to find out if there was a positive, zero or negative correlations in the testing of the research hypothesis. A research design is an effective planning strategy which is important in solving the problem statement under the constraints of time, cost and scope (Gakuu, Kidombo and Keiyoro, 2018).

\subsection{Respondents}

The target population of the study was 12,622 mango farmers out of which a sample of 375 respondents was determined by use of a table statistical formula (Krejcie and Morgan, 1970). Target population, is the population the researcher wished to generalize into the study findings while the study's accessible population referred to the study actual respondents who formed the sample size (Kyalo, Mulwa, Matula and Gichui, 2018). A pre-test pilot study was undertaken for the validity and reliability of the questionnaire before the main data exercise.

\subsection{Data Collection}

The data for this study was collected using self-administered questionnaires, observation and interview guides. 


\subsection{Data Analysis}

Inferential statistical techniques and descriptive measures of central tendency and measures dispersion were used to present means and standard deviation, Analysis of variance (ANOVA) to describe spread and variation between the variables. The final number of questionnaires analysed were 369 out of the 375.Data was subjected to the test of multicollinearity and singularity, test of homoscedasticity (variance in scores on one predictor variable similarity to all the values of the other variables) and test of heteroscedasticity (variability of a predictor variable i.e. regressors, being unequal across the Cartesian scatter-plot range of values of the dependent variable i.e. regressand, that predicts it) using SPSS forLikert-type data.

\subsection{Quantitative Data Analysis using Correlation Analysis and Regression Models}

The research hypothesis was tested using correlation analysis, which entails no correlation;primarily, when t-test is at 0 point, F-test depicts null hypothesis. The regression models were on the amount of change the independent variable is associated with the changes on the dependent variable, when the two variable are tested. According to (Fisher, 1935), regression model is for findingout how best the goodness of fit in the gradient of the regression line and the amount of change and by how much, if any in a study. This is important because the null hypothesis is usually upheld valid first until it is disapproved or rejected. This means that, the result can be significant or not as in case the originally tested null hypothesis for the lady tasting (i.e. Dr. Blanche Muriel Bristol), who claimed could tell by tasting, if milk was put in tea first or not ((Fisher, 1935).In linear regression estimation model, the null hypotheses $\left(\mathrm{H}_{0}: \mu=0\right)$ is based on a valid claims (which can never be proved! but can be disproved by use of random probabilities) in research and if not so, the researcher 'rejects or fails to reject' the claim and 'accepts' the alternative hypothesis $\left(\mathrm{H}_{1:} \mu \neq 0\right)$.This is in tandem with original hypothesis formulated and tested on whether the p-value coefficient tells the changes are significant or not (Fisher, 1935).

\subsection{Formulation of Null and Alternative Hypothesis}

This research used inferential statistics to test the null hypothesis which stated that:

- $\mathrm{H}_{0}$ : There is no significant relationship between participatory project planning and performance of mango farming projects in Makueni County Kenya.

- $\mathrm{H}_{1}$ : There is a significant relationship between participatory project planning and performance of mango farming projects in Makueni County Kenya.

In this therefore, performance of mango farming projects is a function of $f$ (participatory project planning) i.e.

$\mathrm{Y}=\alpha+\beta_{1} \mathrm{X}_{1}+\varepsilon$

Model: $\mathrm{Y}=\mathrm{f}\left(\mathrm{X}_{2}, \varepsilon\right)$.

\subsection{Ethical considerations}

The researcher sought permission to undertake the study from the University of Nairobi, NACOSTI and the County Government of Makueni. All study information gathered from respondents were never divulged to third parties and was kept in strict confidentiality. Voluntary consent was obtained from the respondents and it was clearly explained that the study was for the academic purpose. In the course acquiring data information for the study, the respondents were never subjected to any form of harm that could have caused injury their right to privacy. Consent was obtained and voluntary participation was maintained. Confidentiality, informed consent and dignity of the respondents was highly respected. Transparency and honesty was also maintained at all times. Any kind of biasness was avoided so as to safeguard the anonymity of the respondents, their integrity and that of the data.

\section{Results and Discussions}

\subsection{Introduction}

The results consist of data analysis, interpretation, presentation and discussion of the research findings. It also presents analysis of tests for statistical assumptions and analysis of Likert-scale data. The study findings are organized into themes following the study objective. The purpose of the study was to establish the influence of Participatory Project Planning and Performance of Mango Farming Projects in Makueni County, Kenya. Key informants' qualitative data were analyzed by use of content analysis. The quantitative data in Likert Scale was analysed by descriptive and inferential statistics, means and F-tests, regression models and Pearson correlation was used for testing of the research hypothesis.

\subsection{Respondent's Return Rate}

The target population 375.0 ut of the 375 questionnaires, 369 questionnaires which was $98.4 \%$ of the total respondents were returned; a value considered adequate as described by (Richardson, 2005).In the event that some farmers were busy, arrangement was made to collect the filled questionnaires on a later date. The study also conducted face to face interview with 15 the key informants since they were on the ground to assist mango farmers in mango management and technical skills transfer.

\subsection{Demographic Information and Respondents' Profile}

The demographic information of the respondents was based on: gender, age bracket, academic level, occupation and the number of years of cultivating mangoes. The findings are as discussed below: 


\subsubsection{Distribution of Respondents by Gender}

The gender distribution quantified frequency in percentage (\%). The respondents were requested to indicate their gender and the responses presented in Table 4.1.

\begin{tabular}{|c|c|c|}
\hline Gender & Frequency & Percentage (\%) \\
\hline Male & 210 & 56.9 \\
\hline Female & 159 & 43.1 \\
\hline Total & 369 & 100 \\
\hline
\end{tabular}

Table 1: Gender Distribution of Respondents

Table 1 shows majority of respondents, 210 (56.9\%) were male and 159 (43.1\%) female. This shows that more men were involved in Mango Farming Projects than female in Makueni County. This shows that more male respondents were involved in mango farming as opposed to female. These results agree with (Tesfaye, 2015) who argued that the women participation in farming was less than that of their male counterparts. This phenomenon could be explained on the impact of cultural beliefs concerning assets ownership in communities. However, this gender representation was very useful in this study as it could be assumed this disparity was attributed by land ownership tenure systems and community customary factors that remained static in most transitory economies. In another study, it was reported that, in most cases, women labour was considered passive in agriculture and it was neither observed nor quantified (Cisco and Olungah, 2016). They reported further that (Cisco et al, 2016) cultural norms and traditional beliefs excluded most women in the African, from direct land ownership.

Government's effort on gender equity and equality, and public participation anchored in new laws is seen to be reversing those negative tendencies (Kenya constitution, 2010). It was revealed on the need for concerted effort regarding women actual economic participation and public perception to overcome women invisibility in culture and gender roles through gender mainstreaming in agriculture, where mostly the woman labour is neither counted nor quantified (Ghosh et al, 2014). This tallies with a study which revealed that, social capital relationships in agricultural development projects opens up more farming ideas (TaruvingaNdou, Hlerema, Maraganedzha, Plooy and Venter, 2017). Tesfaye (2015) showed that, in the agriculture sector, women performed more work than men although it is believed that land belongs to men in the society. This view was supported by other authors who alluded that women farm-work was unpaid and undervalued for no convincing reasons (Tharaniet al, 2016).

\subsubsection{Distribution of Respondents by Age}

Respondents were requested to indicate age. This indication established the age bracket and their age distribution. Table 2 presents data on age.

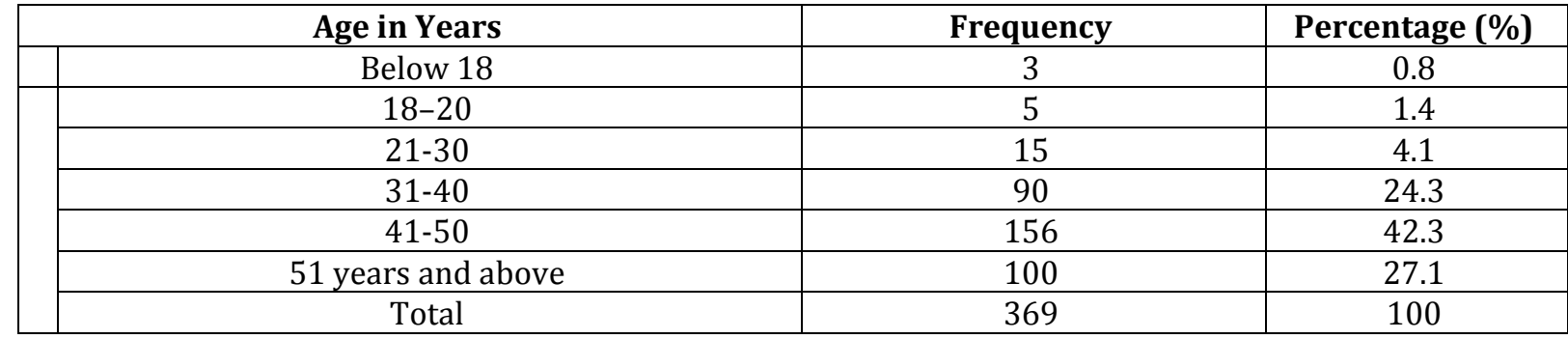

Table 2: Distribution of Respondents' Age

Table 2, shows majority $156(42.3 \%)$ of the respondents were aged between 41-50 years. This was followed by those who were 51 years and above $100(27.1 \%)$ and $31-40(24.3 \%)$ and below 18 years were only $3(0.8 \%)$. This showed that most of those farming mangoes were above 31 years and made up of $93.7 \%$, hence were in a position to take good care of their mango farms. The young people were the minority of the people involved in mango farming, making only $23(6.3 \%)$ of the respondents. This agrees with (Tharanathan et al, 2006) who argued majority farming were adults, not youth. Nevertheless, (Latopa, Norazizan and Rashid, 2015), reported that youth unemployment could be reduced through capacity building in agriculture to reactivate and reawaken youth potential in agricultural empowerment programmes. This study found out that those below 18 years were only $3(0.8 \%)$ in school or college, and those out of college were still under directions of adults who owned the land where mangoes were cultivated.

\subsubsection{Distribution of Respondents the Highest Academic Qualification}

Respondents were requested to indicate academic qualification. This meant establishing the mango farmer's ability to acquire mango farming skills and technical knowhow. Table 3presents the results. 


\begin{tabular}{|c|c|c|}
\hline Academic & Frequency & Percentage (\%) \\
\hline Never went to school & \multicolumn{2}{|l|}{10} \\
\hline Primary & 91 & 24.7 \\
\hline Secondary school & \multicolumn{2}{|l|}{202} \\
\hline Certificate & \multicolumn{2}{|l|}{41} \\
\hline Diploma & \multicolumn{2}{|l|}{10} \\
\hline Degree & 8 & 2.2 \\
\hline Masters & \multirow[t]{2}{*}{4} & 1.1 \\
\hline $\mathrm{PhD}$ & & 0.8 \\
\hline Total & 369 & 100 \\
\hline
\end{tabular}

Table 3: Academic Qualifications of Respondents

Table 3results shows majority 202(54.7\%) had secondary education as their highest level. findings of (Tharani, et al, 2016) argued enhanced participation in Agriculture required at least secondary education. Those who had primary education were 91(24.7\%). It was also noted that very few mango farmers had Post-Secondary Education with $10(2.7 \%)$ diplomas, $4(1.1 \%)$ and $3(0.8 \%)$ with PhDs. This implies that most of the respondents were learned, hence could manage their mangoes farms better.

\subsubsection{Distribution of Respondents by other Occupation}

The study sought to establish other occupations apart from mango farming. This information was important to know whether the mango farmers had other sources of income to assist them in financing their mango projects. Table 4 presents results.

\begin{tabular}{|c|c|c|}
\hline Occupation & Frequency & Percentage (\%) \\
\hline Self-employed & 232 & 62.9 \\
\hline Full-time employment & 38 & 10.3 \\
\hline Temporary employment & 42 & 11.4 \\
\hline Student & 10 & 2.7 \\
\hline Retired & 47 & 12.7 \\
\hline Total & 369 & 100 \\
\hline
\end{tabular}

Table 4: Distribution of Respondents' Other Occupation

Majority 232(62.9\%) were self-employed. This means that they were likely to finance and have enough time to take care of their mango projects. This was followed by 47(12.7\%) who were retired and had started mango farming. It was noticed that only a few farmers $42(11.4 \%)$ and $10(2.7 \%)$ had temporary employment and others students respectively.

\subsubsection{Distribution of Respondents by Number of Years in Mango Farming}

The study sought to establish the number of years the respondents were involved in mango farming projects. Establishing the experience of the farmers was important in this study since experienced farmers were likely to provide reliable information for this study. The responses were presented in Table 5.

\begin{tabular}{|c|c|c|}
\hline Experience in Years & Frequency & Percentage (\%) \\
\hline $1-5$ & 10 & 2.7 \\
\hline $6-10$ & 122 & 33.1 \\
\hline $11-15$ & 170 & 46.1 \\
\hline $16-20$ & 41 & 11.1 \\
\hline $21-25$ & 10 & 2.7 \\
\hline $25-30$ & 12 & 3.2 \\
\hline 31 and above & 4 & 1.1 \\
\hline Total & 369 & 100 \\
\hline Table 5: Distribution of Respondents' Number of Years in Mango Farming
\end{tabular}

This study established majority $170(46.1 \%)$ had been doing mango farming for 11-15 years. This was followed by $122(43.1 \%)$ who had been doing mango farming for 5-10 years. It was noted that, very few mango farmers had been in mango farming for between 21 and above 31 years making a total of only 18.1\%. Also very few had 1-5 years' experience $10(2.7 \%)$. These results showed that the respondents had good experience and were likely to provide reliable information.

\section{Participatory Project Planning and Performance of Mango Farming Projects}

\subsection{Descriptive and Inferential Statistical Analysis}

The results of the Descriptive and Inferential Statistical Analyses were done on Participatory project planning and performance of mango farming projects. Likert-scale type of questions were used in this study ranging from 1-5 differentiated as Likert item wherein, a single item was used to measure a single variable and Likert Scale (Brown, 2011). 
Ibid, Brown argued that, Likert scale data can be analysed as an interval measurement scale in all descriptive and statistical data analyses. These scales were created by this researcher and involved calculating a composite score (sum or mean) from Likert type items data. The composite score for the Likert scales were analysed as an interval measurement scale after which various data analysis procedures for interval scale items were applied. According to (Carifio and Racco, 2007), when using 5 point Likert-scale, the following are the scoring; strongly Agree ( $S A$ ) $4.2<S A<5.0$, Agree; $3.4<A<4.2$, Neutral; $2.6<N<3.4$, Disagree; $1.8<D<2.6$, Strongly Disagree; $1<S D<1.8$. The scale gives an equidistance of 0.8 within the range of measurements. This weighting criterion was followed in data analysis of Likert-Scale type of data in this study. These scales were used successfully by (Obare, Kyalo and Mulwa, 2016).

The descriptive analysis of the study sought to determine on how participatory project planning influenced performance of mango farming projects in Makueni county Kenya. To achieve this objective, descriptive and inferential statistics were used. To measure how participatory project planning influenced performance of mango farming projects, the following indicators were used; mango production planning and forecasting of mango marketing plans. Twelve (12) Likert scale items were presented to the respondents and they were requested to indicate their level of agreement with the given statement on a scale of 1 to 5 with, $\mathrm{SD}=$ strongly disagree, $\mathrm{D}=$ disagree, $\mathrm{N}=$ neutral, $\mathrm{A}=$ agree and $\mathrm{SA}=$ strongly agree. The results in Table 4 shows all the descriptive analysis details.

\subsubsection{Descriptive Analysis of Likert-Type Data}

Descriptive Analysis of Likert-Type data on Participatory Project Planning and performance of mango farming projects is depicted in Table 6, in detail:

\begin{tabular}{|c|c|c|c|c|c|c|c|c|}
\hline No. & Statement & $\begin{array}{c}\text { SD } \\
\text { F } \\
(\%)\end{array}$ & $\begin{array}{c}\text { D } \\
\text { F } \\
(\%)\end{array}$ & $\begin{array}{c}\mathbf{N} \\
\mathbf{F} \\
(\%)\end{array}$ & $\begin{array}{c}A \\
F \\
(\%)\end{array}$ & $\begin{array}{c}\text { SA } \\
\text { F } \\
(\%)\end{array}$ & Mean & SD \\
\hline $13 a$ & $\begin{array}{c}\text { There are continuous participatory } \\
\text { planning before actual planting of mango } \\
\text { seedlings }\end{array}$ & $\begin{array}{c}51 \\
(13.8)\end{array}$ & $\begin{array}{c}96 \\
(26.0)\end{array}$ & $\begin{array}{c}88 \\
(23.8)\end{array}$ & $\begin{array}{c}59 \\
(16.0)\end{array}$ & $\begin{array}{c}75 \\
(20.3)\end{array}$ & 3.03 & 2.82 \\
\hline $13 \mathrm{~b}$ & $\begin{array}{l}\text { seminars for transferring information to } \\
\text { mango farmers to increase production } \\
\text { are not conducted }\end{array}$ & $\begin{array}{c}42 \\
(11.4)\end{array}$ & $\begin{array}{c}55 \\
(15.0)\end{array}$ & $\begin{array}{c}96 \\
(26.0)\end{array}$ & $\begin{array}{c}100 \\
(27.1)\end{array}$ & $\begin{array}{c}93 \\
(25.2)\end{array}$ & 3.5 & 3.19 \\
\hline $13 c$ & $\begin{array}{c}\text { Participatory planning is done for prolific } \\
\text { seedlings that can increase mango } \\
\text { production }\end{array}$ & $\begin{array}{c}33 \\
(8.9)\end{array}$ & $\begin{array}{c}51 \\
(13.8)\end{array}$ & $\begin{array}{c}112 \\
(30.4)\end{array}$ & $\begin{array}{c}95 \\
(25.7)\end{array}$ & $\begin{array}{c}78 \\
(21.1)\end{array}$ & 3.4 & 4.05 \\
\hline $13 d$ & $\begin{array}{c}\text { There are not government } \\
\text { implementation and regulatory plans in } \\
\text { mango farming }\end{array}$ & $\begin{array}{c}77 \\
(20.9)\end{array}$ & $\begin{array}{c}123 \\
(33.3)\end{array}$ & $\begin{array}{c}98 \\
(26.6)\end{array}$ & $\begin{array}{c}31 \\
(8.4)\end{array}$ & $\begin{array}{c}30 \\
(8.1)\end{array}$ & 2.4 & 4.37 \\
\hline $13 \mathrm{e}$ & $\begin{array}{l}\text { Mango farmers are trained to be effective } \\
\text { in use agrochemicals for prevention of } \\
\text { mango pests }\end{array}$ & $\begin{array}{c}164 \\
(44.4)\end{array}$ & $\begin{array}{c}99 \\
(26.8)\end{array}$ & $\begin{array}{c}12 \\
(3.3)\end{array}$ & $\begin{array}{c}64 \\
(17.3)\end{array}$ & $\begin{array}{c}30 \\
(8.1)\end{array}$ & 2.9 & 4.41 \\
\hline $13 \mathrm{f}$ & $\begin{array}{l}\text { There are no working plans for funding } \\
\text { mango farmers to increase mango output }\end{array}$ & $\begin{array}{c}26 \\
(7.0)\end{array}$ & $\begin{array}{c}26 \\
(7.0)\end{array}$ & $\begin{array}{c}50 \\
(13.6)\end{array}$ & $\begin{array}{c}79 \\
(21.4)\end{array}$ & $\begin{array}{c}183 \\
(50.7)\end{array}$ & 3.9 & 5.48 \\
\hline $13 \mathrm{~g}$ & $\begin{array}{l}\text { There are various mango actors in your } \\
\text { area who assist mango farmers in cash } \\
\text { and in kind } \\
\end{array}$ & $\begin{array}{c}100 \\
(27.1)\end{array}$ & $\begin{array}{c}125 \\
(33.9)\end{array}$ & $\begin{array}{c}60 \\
(16.3)\end{array}$ & $\begin{array}{c}50 \\
(13.6)\end{array}$ & $\begin{array}{c}34 \\
(9.2)\end{array}$ & 2.4 & 5.50 \\
\hline $13 \mathrm{~h}$ & $\begin{array}{c}\text { The county government agricultural } \\
\text { extension officers are not always } \\
\text { available to mango farmers }\end{array}$ & $\begin{array}{c}102 \\
(27.6)\end{array}$ & $\begin{array}{c}79 \\
(21.4)\end{array}$ & $\begin{array}{c}23 \\
(6.2)\end{array}$ & $\begin{array}{c}99 \\
(26.8)\end{array}$ & $\begin{array}{c}66 \\
(17.9)\end{array}$ & 3.3 & 5.67 \\
\hline $13 \mathrm{i}$ & $\begin{array}{l}\text { You plan well in advance to control the } \\
\text { onset of diseases and pests before they } \\
\text { infest mangoes }\end{array}$ & $\begin{array}{c}10 \\
(2.7)\end{array}$ & $\begin{array}{c}15 \\
(4.1)\end{array}$ & $\begin{array}{c}79 \\
(21.4)\end{array}$ & $\begin{array}{c}135 \\
(36.6)\end{array}$ & $\begin{array}{c}130 \\
(35.2)\end{array}$ & 4.0 & 6.39 \\
\hline $13 \mathrm{j}$ & $\begin{array}{c}\text { You plan well in advance for use of } \\
\text { quality mango seedlings and rootstocks }\end{array}$ & $\begin{array}{c}12 \\
(3.3)\end{array}$ & $\begin{array}{c}20 \\
(5.4)\end{array}$ & $\begin{array}{c}81 \\
(22)\end{array}$ & $\begin{array}{c}120 \\
(32.5)\end{array}$ & $\begin{array}{c}136 \\
(36.9)\end{array}$ & 3.9 & 6.3 \\
\hline 13k & $\begin{array}{l}\text { You have already planned market } \\
\text { channels to sell your mangoes }\end{array}$ & $\begin{array}{c}59 \\
(16.0)\end{array}$ & $\begin{array}{c}84 \\
(22.8)\end{array}$ & $\begin{array}{c}76 \\
(20.6)\end{array}$ & $\begin{array}{c}100 \\
(27.1)\end{array}$ & $\begin{array}{c}50 \\
(13.5)\end{array}$ & 3.0 & 6.58 \\
\hline \multirow[t]{3}{*}{131} & $\begin{array}{l}\text { Mango farming inputs are not expensive } \\
\text { to most farmers }\end{array}$ & $\begin{array}{c}11 \\
(3.0)\end{array}$ & $\begin{array}{c}17 \\
(4.6)\end{array}$ & $\begin{array}{c}74 \\
(20.1)\end{array}$ & $\begin{array}{c}137 \\
(37.1)\end{array}$ & $\begin{array}{c}130 \\
(35.2)\end{array}$ & 4.1 & 7.19 \\
\hline & Composite mean and standard deviation & & & & & & 3.25 & 5.16 \\
\hline & \multicolumn{5}{|c|}{$\begin{array}{c}\mathrm{n}=369 \\
\text { Composite mean }=3.25 \\
\text { Composite standard deviation }=5.16 \\
\text { Cronbach's Alpha (a) Reliability coefficient }=0.851\end{array}$} & & & \\
\hline
\end{tabular}

\section{Table 6: Participatory Project Planning}

Table 4.14 revealed composite mean (M) for the performance of mango farming projects was 3.25 and the standard deviation was 5.16. The Cronbach's Alpha (a) Reliability coefficient used to measure performance of mango farming projects was 0.851 . This showed that the items had very strong internal consistency. 
Item 13a required respondents' opinion on the statement that, there were continuous participatory planning before actual planting of mango seedlings. Results showed $26 \%$ they disagreed, while $23.8 \%$ were neutral. The item had mean of 3.03 and SD of 2.82 indicating they s were neutral. The mean was less than the composite mean implying that the participatory project planning before actual planting had no influence on the performance of mango projects. Further item $13 \mathrm{~b}$ sought to determine opinion of the respondents on the statement that, seminars for transferring information to mango farmers to increase production were not conducted. The results indicated that $27.1 \%$ agreed while $26 \%$ were neutral. The item had mean of 3.5 and SD of 3.19 indicating that the respondents being neutral. The mean was more than the composite mean implying that the seminars for transferring information to mango farmers had influence on the performance of mango projects. These results agree with the key informants' report which indicated that seminars were good because they helped farmers to gain new knowledge leading to improved performance. The same results were echoed by one farmer during the interview who said that;

'We have never seen anyone coming to train us on mango production, so we only depend on information from friends which sometimes is very scanty and misleading'.

These findings were in agreement with (Arinloyeet al, 2017) seminars and training in agriculture and found out that, lack of adequate seminars and training affected agriculture in the initial stages. This in turn led to preharvest problems and poor handling in post-harvesting of mangoes, compromising quality in local and global markets. It also led to losses and lower prices in the long run, thus predisposing mango production to many financial constraints in whole mango value chain development. One of the mango farmers on the same issue said that;

"Mango Farmers need financial assistance during the planning of their mango projects since farm inputs and seedlings are very expensive to afford by most farmers"

Item 13c sought to determine opinion of the respondents on the statement that, participatory project planning is done for prolific seedlings that can increase mango production. The results indicated that $30.4 \%$ of the respondents were neutral about the statement while $25.7 \%$ agreed. The item had mean of 3.4 and SD of 4.05 indicating neutral about the statement. The mean was slightly more than the composite mean implying the item had some influence on performance. Further, item $13 \mathrm{~d}$ sought to determine opinion on the statement that, there are no government implementation and regulatory plans in mango farming. Results indicate $33.3 \%$ respondents disagreed while $26.6 \%$ were neutral. The item had mean of 2.4 and SD of 4.37 showing respondents disagreed. The mean was less than the composite mean implying government implementation and regulatory plans in mango farming had no influence on the performance of mango projects. These results are in line with what the respondents who said;

'We do not know the importance of the government implementation and regulatory plans in mango farming if at all they are there in existence'.

The key informants also indicated that, although government implementation and policy regulatory plans in mango farming were there, little has been done in Makueni County. The results also agree with Turner (1999), who argued that, though project planning plays a major role in having well implemented projects. Most Governments do very little that lead to improved performance of mango farming projects. Project planning entails considerations of all project resources. Mbeche et al, (2013) revealed that planning for implementation led to sound executed projects.

Item $13 \mathrm{f}$ sought to determine opinion of the respondents on the statement that, there were no working plans for funding mango farmers to increase mango output. Results indicated majority (50.7\%) strongly agreed with the statement while $13.6 \%$ were neutral. The item had mean of 3.9 and SD of 4.41 indicating that they agreed with the statement. This mean was more than the composite mean implying funding mango farmers had influence on the performance of mango projects. These results agree with what the key informants who indicated that mango farming required a lot of funds although the government was not financing mango famers well. Also one of the farmers said;

'We just hear that there are people funded by the government to do mango farming but there seems to be no working plans for funding mango farmers to increase mango output'.

Item $13 \mathrm{~g}$ determined opinion of the respondents on the statement that, there were various mango statement while $16.3 \%$ were neutral. The item had a mean of 2.4 and standard deviation (SD) of 3.2 indicating that the respondents were neutral about the statement. These results were however not in line with a mango farmer who said,

'There were very few mango actors in our area who assist mango farmers in cash and in kind and very few people have benefited from the same.'

Item $13 \mathrm{~h}$ sought to determine opinion of the respondents on the statement that, the county government agricultural extension officers are not always available to mango farmers. The results indicated that $27.6 \%$ ) disagreed and $26.8 \%$ agreed. The item had mean of 3.3 and SD of 3.7 indicating that the respondents were neutral about the statement. This mean was less than the composite mean implying item had influence on mango projects. Item 13i sought to determine opinion of the respondents on the statement that, they plan well in advance to control the onset of diseases and pests before they infest mangoes are not government implementation and regulatory plans in mango farming. Results indicated $36.6 \%$ agreed with the statement while 35.2\% strongly agreed. The item had mean of 3.2 and SD of 4.1 indicating they were neutral about the statement. Item 13j sought to determine opinion of the respondents on the statement that, they planned well in advance for use of quality mango seedlings and rootstocks. The results indicated $36.9 \%$ of strongly agreed while $32.5 \%$ strongly agreed. The item had mean of 3.9 and SD of 3.3 indicating respondents were in agreement with the statement.

Item 13k sought to determine opinion of the respondents on the statement that, they had already planned market channels to sell their mangoes. Results indicated $27 \%$ agreed with the statement while $20.6 \%$ were neutral. The item had mean of 3.0 and SD of 3.8 indicating were neutral about it. Item 13l sought to determine opinion of the respondents on the 
statement that, mango farming inputs were not expensive to most farmers. The results indicated $37.1 \%$ agreed with the statement while $35.2 \%$ strongly agreed. The item had mean of 4.1 and SD of 3.9 indicating agreement with the statement.

\subsubsection{Hypothesis Testing}

The null and the alternative were set because, according (Fisher, 1935; Fisher, 1925) in hypothesis testing, $\mathrm{H}_{0}$ and $\mathrm{H}_{1}$ for rejecting or failing to reject criterion; the rejection criterion in any study as put forth in his study book for Statistical Methods for research Workers. Null hypothesis is the one that is tested, ibid, according Ronald Aylmer Fisher. And hence, the research null hypothesis was tested this study:

- $\mathrm{H}_{0}$ : There is no significant relationship between participatory project planning and performance of mango farming projects in Makueni County Kenya.

- $\mathrm{H}_{1}$ : There is a significant relationship between participatory project planning and performance of mango farming projects in Makueni County Kenya.

In this study, the hypothesis stated in the null and alternative in order to reject or fail to reject in comparison to the comparative analogy advanced by (Fisher, 1935).

Linear Regression Model:Performance of Mango Farming Projects being the dependent variable is a function of $f$ (participatory project planning variable), and hence the linear regression model:

$\mathrm{Y}=\mathrm{f}\left(\mathrm{X}_{1}, \mathrm{X}_{2}, \varepsilon\right)$,

$Y=\alpha+\beta_{0} X_{1}+\beta_{1} X_{2}+\varepsilon$,

$Y=\alpha+\beta_{0} X_{2}+\varepsilon$,

Model: $\mathrm{Y}=f\left(\mathrm{X}_{2}, \varepsilon\right)$.

\subsubsection{Relationship between Participatory Project planning and Performance of Mango Farming Projects}

Pearson's moment correlation technique was used to determine the relationship between Participatory Project planning and Performance of Mango Farming Projects. The results are in Table 7 below.

\begin{tabular}{|c|c|c|c|}
\hline & & $\begin{array}{c}\text { Participatory } \\
\text { Project Planning }\end{array}$ & $\begin{array}{c}\text { Performance of Mango } \\
\text { Farming Projects }\end{array}$ \\
\hline Participatory Project planning & Pearson Correlation & 1 & $.522\left(^{* *}\right)$ \\
\hline & Sig. (2-tailed) & & .000 \\
\hline $\begin{array}{c}\text { Performance of Mango Farming } \\
\text { Projects }\end{array}$ & Pearson Correlation & $.522\left(^{* *}\right)$ & 369 \\
\hline & Sig. (2-tailed) & .000 & 369 \\
\hline
\end{tabular}

Table 7: Correlation between Participatory Project Planning and Performance of Mango Farming Projects ** Correlation is significant at the 0.01 level (2-tailed)

The Table 7 Results shows that, there was a significant positive relationship between Participatory Project Planning and Performance of Mango Farming Projects depicting ( $r=0.522, p=0.000)$. This infers that there was a strong association between Participatory Project planning and Performance of Mango Farming Projects.

\begin{tabular}{|c|c|c|c|c|c|c|}
\hline \multicolumn{7}{|c|}{ Model Summary } \\
\hline Model & $\mathrm{R}$ & R Square & $\begin{array}{l}\text { Adjusted R } \\
\text { Square }\end{array}$ & $\begin{array}{l}\text { Std. Error of the } \\
\text { Estimate }\end{array}$ & & \\
\hline 1 & $.339(\mathrm{a})$ & 0.115 & 0.067 & 0.213 & & \\
\hline \multicolumn{7}{|l|}{ ANOVA (b) } \\
\hline Model & & Sum of Squares & Df & Mean Square & $\mathrm{F}$ & Sig. \\
\hline \multirow[t]{3}{*}{1} & Regression & 0.218 & 2 & 0.109 & 2.402 & $.000(\mathrm{a})$ \\
\hline & Residual & 1.682 & 367 & 0.045 & & \\
\hline & Total & 1.9 & 369 & & & \\
\hline \multicolumn{7}{|l|}{ Coefficients (a) } \\
\hline \multirow[t]{2}{*}{ Model } & & \multicolumn{2}{|c|}{$\begin{array}{l}\text { Unstandardized } \\
\text { Coefficients }\end{array}$} & $\begin{array}{c}\text { Standardized } \\
\text { Coefficients }\end{array}$ & $\mathrm{T}$ & Sig. \\
\hline & & $\mathrm{B}$ & Std. Error & Beta & $\mathrm{B}$ & Std. Error \\
\hline 1 & (Constant) & 0.881 & 0.098 & & 9.016 & 0 \\
\hline & $\begin{array}{l}\text { Participatory } \\
\text { Project } \\
\text { planning }\left(\mathrm{X}_{2}\right)\end{array}$ & 0.095 & 0.065 & 0.541 & 1.469 & 0 \\
\hline
\end{tabular}

Table 8: Simple Linear Regression Results for the Association between Participatory

Project Planning and Performance of Mango Farming Projects

a. Dependent Variable: Performance of Mango Farming Projects

b. Predictor Variable:Participatory Project Planning 
The results from Table 8 shows that, $\mathrm{DF}(2,367) \mathrm{F}=2.402, \mathrm{t}=1.469$ with level of significance $\mathrm{P}=0.000<0.05, \mathrm{r}=0.339$ and $R$ square $=0.115$. The results signified that $5 \%$ level significance and $95 \%$ level of significance the test statistically significant and therefore, the null hypothesis was rejected.

Table 4.16 Results depicts adjusted $\mathrm{R}$ squared is 0.067 which infers $6.7 \%$ of the variations in performance of mango farming projects were influenced by Participatory Project planning, while the other variations are determined by other factors outside the model. Again, the ANOVA results indicated that the model was statistically significant, F $(2,367)$ $=2.402$ with a p-value $=0.000$. In fitting the best fit of least squares method as illustrated on Table 8 , the researcher obtained the model Y= a (constant) $+\mathrm{BX}$ (beta denotes the gradient amount of change of independent variable had on dependent); this is where $\mathrm{a}=0.881, \mathrm{~b}=9.016$ and $\mathrm{X}=0.095$, which is the Participatory Project Planning.

The linear regression model one therefore is indicated as;

Model 2: $\mathrm{Y}=\mathrm{f}\left(\mathrm{X}_{2}, \varepsilon\right)$,

$Y=\alpha+\beta_{0} X_{2}+\varepsilon$.

The univariate linear regression model is;

$\mathrm{Y}=0.881+0.095 \mathrm{X}_{2}$

Where,

$\mathrm{Y}=$ performance of mango farmers and

$\mathrm{X}_{2}=$ Participatory Project planning

The beta values of 0.095 infers that, one unit increase in Participatory Project planning increased performance of mango farming projects by 0.095 units and vice versa. This confirms that Participatory Project planning had significant influence on performance of mango farming projects. It could also be seen from Table 8 that, the linear regression F-test relationship between the two variables $\mathrm{Y}$ and $\mathrm{X}_{2}$ had a correlation relationship of $\mathrm{R}^{2}=0.115$, $\mathrm{DF}(2,367)$ degrees of freedom and of F-test (2.402) and with a p-value of .000; meaning that the test was significant. With the null hypothesis $\mathrm{H}_{1}$ rejected it was concluded further there was a significant relationship between the Participatory Project planning in the overall Performance of mango Projects.

On Project planning has been shown that, planning for implementation was important as it improved project success and quality (Mbeche et al, 2013). It was reported by Aref (2011), that participation in agricultural planning was important in farming community. This tallies with a study by (Pryor and Taneja, 2010), found out that in the theory management, Planning was a key component which entailed success of projects. Chalekian (2013) in his revising of POSDCORD analogy of 1937, demonstrated the importance of project planning. This implied that participatory project planning is needed to enhance mango production.

\section{Conclusion}

The studyfound that, there was a significant relationship between participatory project planning and performance of mango farming projects in Makueni County, Kenya.Mango farmers should always have detailed planning in place before starting their mango farming projects. From the interviews conducted and from the key informants, there should always be continuous participatory project planning processes before actual planting of mango seedlings in the mango orchards. The study concluded that, mango farming projects should consider comprehensive participatory project planning before engaging in mangoes farming projects to enhance mango performance.

\section{Recommendation}

The recommendation is on planning for practice, policy formulation and its execution. Robust planning practices are able to enhance performance of the mango fruit. From literature and the findings of this study, it was clear that the mango fruit being the basis of this study, was basically grown for households' consumption and trade, to increase income as well as means of unlocking other socio-economic development opportunities, which improve on rural community living standards. Through participatory project planning, performance of the mango fruit can be improved. From literature, it is evident that, the mango sector has many stakeholders; governments, buyers, financers and project managers, mango farmers, including many other interested parties and meso-actors in whole mango agribusiness value chain. Unfortunately, the national policy and legislative framework have not prioritized the mango fruit as of sound economic value, requiring robust agricultural agribusiness venture when addressing environmental degradation problems in the ASALs,since it is important in enhancing mango performance and controlling of climate change and global warming in mango growing Zones.

\section{References}

i. Amadi (2017). Josphat O. Amadi, School of Continuing and Distance Education, University of Nairobi, Developing Country Studies, www.iiste.org, ISSN 2224-607X (Paper) ISSN 2225-0565 (Online) Vol.7, No.1, 2017. https://www.iiste.org/Journals/index.php.

ii. Agrawal, V. K., \&Vashistha R. (2013). POSDCORB: A Managerial Overview Paripex - Indian Journal Of Research Volume: 3 | Issue: 4 | May 2013 ISSN - 2250-199.

iii. Ambuko, J (2019). Senior lecturer and postharvest specialist, Department of Plant Science and Crop Protection, University of Nairobi, https://www.hortinews.co.ke/2019/01/30/exploiting-the-value-of-mango-fruit-duringpeak-season.

iv. Anderson R.S., Tantoh D.M., Akotsen-Mensah C., Osei-Safo D. \&AfrehNuamah K., (2016). Evaluation of Traps and Attractants for Monitoring the Mango Stone Weevil SternochetusMangiferae (Coleoptera: Curculionidae) In Managed Orchards in Southern Ghana. ASJ: International Journal of Agricultural Research, Sustainability, and 
Food Sufficiency (IJARSFS) Vol. 3(2) 25 April, 2016, Pp. 41-51, ISSN: 2360-932X, Academia Scholarly Journals www.academiascholarlyjournal.org/ijarsfs/index_ijarsfs.htm.

v. Aref, F., (2011). Farmers' Participation in Agricultural Development: the Case of Fars Province, Iran in Indian Journal of Science and Technology, Volume 4, Issue 2, February 2011, 4(2):155-158 D0I: 10.17485/ijst/2011/v4i2/29952 http://indjst.org/index.php/indjst/article/view/29952.

vi. Arinloye, A. D., Degrande, A., Hotegni, V. N. F., Asaah, E., Bockarie, R., Nyemeck, J. B., Bayala, J., \&Kalinganire, A. (2017). Value chain development for mango (Mangiferaindica) around OutambaKilimi National Park in Sierra Leone: constraints and opportunities for smallholders. Agriculture \& Food Security volume 6, Article number: 14 (2017).

vii. Arnstein, S. R., (1969). A Ladder of Citizen Participation Theory. Journal of the American Planning Association, 35 (4), $216-224$.

viii. Brown, J.D. (2011). Likert Items and scales of measurements. CHIKEN: JALT Testing and Evaluation. SIG newsletter, March 2011, 15 (1) PP 10-14.

ix. Burondkar M. M., Kulkarni M. M., Salvi B. R., Patil K. D., Narangalkar A. L., Joshi M. S., Talathi J. M. , Naik V. G., Malave D. B., Bhosale S. S., Deorukhakar A. C., Bagade S. R., Patil V. K., Rane A. D., Dodake S. B., Haldankar P. M. \& Bhattacharyya T. (2018). Mango: An Economic Pillar of Konkan Region of Maharashtra, Advanced Agricultural Research \& Technology Journal no. Vol. II, no Issue 2 no July 2018, ISSN: 2581-3749 (online).

X. Carifio, J. and Racco, J.P. (2007). Ten common misunderstanding, misconceptions, persistence myths and urban

xi. Chalekian, P., (2013). POSDCORB: Core Patterns of Administration, University of Nevada, Reno Department of Political Science, Research information.

https://www.researchgate.net/publication/271839970_POSDCORB_Core_Patterns_of_Administration.

xii. Choudhary, M. P, Chauhan, G. S \&Kushwah, Y. K (2015) Environmental Degradation: Causes, Impacts and Mitigation, Conference: National Seminar on Recent Advancements in Protection of Environment and its Management Issues (NSRAPEM-2015) At: Maharishi Arvind College of Engineering and Technology,

xiii. Chinn \& Kramer (1999).Theoretical Framework vs. Conceptual Framework, StudyMode.com, http://www.studymode.com/essays/Theoritical-Framework-Vs-Conceptual-Framework-825118.html.

xiv. Cisco, O.B., \&Olungah, C.O., (2016). Factors Affecting Rural Women's Participation in Agriculture for Development in Gatundu South Sub County, Kiambu County, Kenya. International Review of Social Sciences and Humanities Vol. 11, No. 2 (2016), pp. 97-107 www.irssh.com, ISSN 2248-9010 (Online), ISSN 2250-0715 (Print). http://www.irssh.com/yahoo_site_admin/assets/docs/8_IRSSH-1340-V11N2.249105418.pdf.

xv. Dessalegna Y., Habtemariam A., Derso T., Teferad, M (2014). Mango Production Knowledge and Technological Gaps of Smallholder Farmers in Amhara Region, Ethiopia. American Scientific Research Journal for Engineering, Technology, and Sciences (ASRJETS) (2014) Volume 10, No 1, pp. 28-39, ISSN (Print) 2313-4410, ISSN (Online) 2313-4402.

xvi. Dubin, Simon (1976). https://books. Google.co.ke/books? Id=JUKTMx8ZeKsC\&pg=PA9\&dq

xvii. FAO, (2017). Food And Agriculture Organization of the United Nations Rome, 2017, http://www.fao.org/3/ai7808e.pdf.

xviii. FAO, (2017). Increasing the Yield of Mango with Selective Harvest, Food and Agriculture of the United Nations,

xix. Fayol, H. (1916). Administration industrielle et générale; prévoyance, organisation, commandment, coordination,

xx. Fisher, R. A. (1935). The design of experiments. Oliver \& Boyd, London, UK. https://psycnet.apa.org/record/1939-04964-000.

xxi. FSD Kenya, (2015). Opportunities for financing the mango value chain: a case study of Lower Eastern Kenya, contribution of William Grant - DAI, Esther Kadondi, Michael Mbaka and Silas Ochieng, http://s3-eu-central1.amazonaws.com/fsd-circle/wp-content/uploads/2015/08/30093918/15-06-29-Mango-value-chainreport.pdf.

xxii. Gakuu C.M, Kidombo H.J \&Keiyoro P.N, (2018). Fundamentals Research Methods: Concepts, Practice and Applications.

xxiii. Ghosh M., \& Ghosh, A., (2014). Analysis of Women Participation in Indian Agriculture. OSR Journal of Humanities and Social Science (IOSR-JHSS) Volume 19, Issue 5, Ver. IV (May. 2014), PP 01-06e-ISSN: 2279-0837, p-ISSN: 2279-0845.www.iosrjournals.org.

xxiv. Goldratt, E.M., (1990). What is this Thing Called Theory of Constraints (1990) ISBN 0-88427-166-8.

xxv. Gulick, L., \&Urwick, L., (1937). Papers on the Science of Administration. Pp. vii, 195. New York: Institute of Public Administration, 1937, Leonard D. White First Published May 1, 1938, The ANNALS of the American Academy of Political and Social Science, https://doi.org/10.1177/000271623819700157.https://journals.sagepub.com/doi/abs/10.1177/

xxvi. Hart, T., Burgess, R., Beukes, 0 \& Hart, C (2005). Reducing Pitfalls in Agricultural Development Projects: A Case for the Participatory Project Management Cycle (PPMC), S. Afr. Tydskr. Landbouvoorl. /S. Afr. J. Agric. Ext., Hart, Burgess, Beukes\& Hart, ISSN 0301-603X, Vol 34(1), 2005.

xxvii. Hart, T., Burgess, R., \& Cornel, H., (2005). A participatory project management cycle: can it add value to agricultural development? South African Journal of Agricultural Extension ISSN 0301-603X, Vol. 34(2) 2005: 201-220, https://www.ajol.info/index.php/sajae/article/view/3670.

xxviii. HCDA (2010). Horticultural Crops Production Report 2010, available at www.hcda.or.ke,

a. Horticultural Crops Development Authority (HCDA), Nairobi, Kenya. 
xxix. KARI (2008). Kari-Mutwapa Adaptive Research Programme, Kenya Agricultural Research Institute.KARI\%20MTWAPA\%20ADAPTIVE\%20RESEARCH\%20PROGRAMME\%202007.pdf.

xxx. Kaushik, V., and Walsh, C. A., (2019). Pragmatism as a Research Paradigm and Its Implications for Social Work Research. MDPI Social sciences. Soc. Sci. 2019, 8, 255; doi: 10.3390/socsci8090255 www.mdpi.com/journal/socsci.

xxxi. Kenya Constitution (2010). Http:

//kenyalaw.org/kl/fileadmin/pdfdownloads/bills/2018/PublicParticipationBill_2018.pdf

xxxii. Kenya Vision 2030 (2008). https://vision2030.go.ke.

xxxiii. KNBS (2019). https://knoema.com/atlas/sources/KNBS

xxxiv. Korir, M. K., Mutwiwa, U., Kituu, G. M. \&Sila, D. N. (2017). Thesis, on Assessment of Postharvest Challenges of Mango Fruits In Upper Athi River Basin, Kenya, Department of Biomechanical and Environmental Engineering, Jomo Kenyatta University of Agriculture and Technology, Nairobi, Kenya.

xxxv. Kuhn, T.S. (1962). The structure of scientific revolutions. Chicago Uni. Chicago Press.

xxxvi. Kyalo, D.N., Mulwa, A.S \&Nyonje, R.O (2015). Monitoring and Evaluation of Projects and Programmes: A Hand Book for Students and Practitioners. Nairobi: Aura Books-ISBN 9966- 035-13-4; 2 ${ }^{\text {nd }}$ Ed. 2015.

xxxvii. Kyalo, D., N., Mulwa, A., S., Matula, P., Z., \&Gichui, L., W., (2018). Academic Research Proposal Writing, Principles, concepts and Structure, ISBN 978-9966-1873-2-1, Pub. Nairobi, Kenya.

xxxviii. Latopa, A.A.L., \&Norazizan, S.,Rashid, S.A., (2015). Identifying the Causes of Decline in Youth Participation in Agricultural Empowerment Program Of Youth Integrated Training Farm, Malete, Kwara State, Nigeria, Research on Humanities and Social Sciences www.iiste.org, ISSN (Paper) 2224-5766 ISSN (Online) 2225-0484 (Online), Vol.5, No.7, 2015. https://www.iiste.org/Journals/index.php/RHSS/article/viewFile/21584/22288.

xxxix. Mathieu, L., \&Joas, J (2007). An overview of preharvest factors influencing mango fruit growth, quality and postharvest behaviour. Brazilian Journal of Plant Physiology, On-line version ISSN 1677-9452, Braz. J. Plant Physiol. vol.19 no.4 Londrina Oct./Dec. 2007. http://dx.doi.org/10.1590/S1677-04202007000400004.

xl. Manfred- Max-Neef (1991). Human Scale Development Conception, Application And Further Reflections, Published in 1991 by The Apex Press, an imprint of the Council on International and Public Affairs, 777 United Nations Plaza, New York, New York, USA (212/953-6920) and 57 Caledonian Road, London, N1 9BU, U.K. (01837-4014).

xli. Max-Neef, M., Antonio E.H., \&Hopenhayn, M., (1989). 'Human Scale Development: An Option for the Future.' Development Dialogue: A Journal of International Development Cooperation. 1989, 1, 7-80.

xlii. Mbeche, I. M., Nyamwange, O., Magutu, P. 0 and Onsongo, C., (2013). 'An Introduction to Project Management.'

xliii. Mbithe, M. M. (2012). Factors Influencing Mango Value Addition in Kenya: A Case of Group Projects in Makueni

xliv. MIF, (2010). Mango as an opportunity for long-term economic growth in Haiti, Document of the Inter-American

xlv. Mintzberg, H. (1973). The Nature of Managerial Work. New York: Harper \& Row.http://hib510week9.pbworks.com/f/The+Nature+of+Managerial+Work,+Mintzberg+1973.pdf

xlvi. MoALF, 2016. Climate Risk Profile for Makueni. Kenya County Climate Risk Profile Series. The Kenya Ministry of Agriculture, Livestock and Fisheries (MoALF), Nairobi, Kenya.

xlvii. Mugenda, O., \&Mugenda A.G. (2003). Olive M. Mugenda and Abel G. Mugenda, Research Methods, Quantitative and Qualitative Approaches 2003, ISBN 9966-41-107-0., Laba Graphics Nairobi, Kenya.

xlviii. Muthini D.W. (2015), Thesis by Davis NguthiMuthini on Assessment of Mango Farmers' Choice of Marketing Channels in Makueni, Kenya. Department of Agricultural Economics, University of Nairobi, Kenya.

xlix. Neuman, W. L (2007). Social Research Methods: Qualitative and Quantitative Approaches 7th Ed. ISBN 10: 0205-61596-1 ISBN 13: 978-0-205-61596-4, Pearson Publishers, New York, USA.

l. Obare, O. O, Mulwa, A.S. and Kyalo D.N (2016). Implementation process of project control, systems, Project team training diversity and performance of rural construction in Kenya. International Journal of Innovation research and development, Vol 5 Issue 12.

li. Oxfam, (2019). http://www.oxfarmorganic.com/our-products/mangoes/common-challenges-to-mangoproduction-in-kenya/.

lii. Osena, E.D (2011). An Analysis of the Mango Fruit Value Chain in Embu, Emily Dorothy Osena, University of Nairobi, 2011.

liii. PMI's PMBOK (1996). Project Management Institute's, Project Management Book of Knowledge.

liv. Purushottam B., (2015). Challenges facing mango cultivators of India and the feasible solutions. International Journal of Management and Development Studies 4(3): 250-255 (2015)

a. ISSN (Online): 2320-0685. ISSN (Print): 2321-1423.

lv. Pryor, M.G., \&Taneja, S., (2010). 'Henri Fayol, practitioner and theoretician - Revered and reviled', Journal of Management History, Vol. 16 Issue: 4, pp.489-503, https://doi.org/10.1108/17511341011073960.

lvi. Ravishankar, H. \&Misra, A.K. (2010). Good management practices for mango production and trade.

lvii. Rehman, A., Malik, A.U., Ali, H., Alam, M.W \&Sarfraz B., 2015. Preharvest factors influencing the postharvest disease development and mango fruit quality. Journal of Environmental \& Agricultural Sciences. 3:42-47.

lviii. Richardson, S.F., (2005). Project Management for Small Projects, ISBN-10: 156726185X, ISBN- 13: 9781567261851, Publisher: Management Concepts, USA.

lix. Rostow, W. W. (1960). The Stages of Economic Growth: A Non-Communist Manifesto, Ed. 1960. Cambridge: Cambridge University Press. 
lx. Rumawir, J., (2019). The Implementation of Harrod-Domar Economic Growth Model in North Sulawesi, Indonesia. ISSN: 2614-7432; E-ISSN: 2621-2862, International Journal of Applied Business and International Management 4(1):19-30. DOI: 10.32535/ijabim.v4i1.379.

lxi. Sulistyowati, L., \& Ronnie, S., Natawidjaja, S (2016). Commercialization Determinant of Mango Farmers in West Java- Indonesia. I J A B E R, Vol. 14, No. 11, (2016): 7537-755.

lxii. Tashakkori, A., \&Teddlie, C., 1998. Mixed Methodology: Combining Qualitative and Quantitative Approaches. Applied Social Research Methods Series, 46; Thousand Oaks: Sage Publications.

lxiii. Taruvinga, B., Ndou, P., Hlerema, I.N., Maraganedzha, T.L., Plooy, C.P.D., \& Venter, S., (2017). Fostering linking social capital for successful agricultural development projects in South Africa, Agrekon, 56:1, 28-39, D0I: 10.1080/03031853.2017.1283243.

lxiv. Taylor, B., Norbert A., Sinzogan, A., Adandonon, A., Kouagou, A.N., Bello, S., Wargui, R., Anato, F., Ouagoussounon, I., Houngbo, H., Tchibozo, S., Todjihounde, R. \& Jean-François, V., (2018). Records of ants (Hymenoptera: Formicate) from the Republic of Benin, with particular reference to the mango farm ecosystem, J. Insect Biodiversity 008 (1): 006-029, ISSN 2538-1318 (print edition), ISSN: 2147-7612(online edition).http://dx.doi.org/10.12976/jib/2018.08.1.2,http://zoobank.org/urn:lsid:zoobank.org:pub:32F7CCB85F81-483A-83A3-B20D1D511782.

lxv. Tesfaye, E., (2015). Gender Dimension Analysis on Farmers Participation in Agriculture: By: EidmonTesfaye, Paperback 136 pagesISBN-10: 3659782300, ISBN-13: 978-3659782305 - September 18, 2015. Publisher: LAP LAMBERT Academic Publishing (September 18, 2015).

lxvi. Tharanathan, R.N., Yashoda, H.M. \&Prabha, T.N. (2006). Mango (MangiferaIndica L.), 'The King of Fruits'—an Overview, Journal of Food Reviews International Vol. 22: Issue 2, 95-123, DOI: 10.1080/87559120600574493.

lxvii. Tharani, G., Akther, M.S.R., \&Nanthakumaran, A., (2016). Assessment of Women Participation in Agriculture in Vavuniya District, Sri Lanka, Postgraduate Institute of Agriculture, University of Peradeniya, Sri Lanka. 2Vavuniya Campus of the University of Jaffna, Sri Lanka. 15137-Article Text-51373-1-10-20160723.pdf.

lxviii. Thong, L., N \&Nguyen, T., H., (2019). International Journal of Humanities Social Sciences and Education (IJHSSE) Volume 6, Issue 4, April 2019, PP 11-17 ISSN 2349-0373 (Print) \& ISSN 2349-0381 (Online) http://dx.doi.org/10.20431/2349-0381.0604003 www.arcjournals.org.

lxix. Torraco R.J. (2004). Theory-Building Research Methods, Torraco R. J., https://books.google.co.ke/books?hl=en\&lr=\&id=AyMZt9AodEEC\&oi=fnd\&pg=PA351\&dq=Torraco+R.+J.+ (2004), +Theory- Building+ Research +Methods.\&ot.

lxx. Turner, R., (1999). The Handbook of Project-Based Management: ISBN10 0071821783, ISBN13 9780071821780.The_Project_Manager_As_Change_Agent_Leadership,_Influence_and_Negotiation.pdf.

lxxi. UN (2015). United Nations Sustainable Goals, https://www.un.org/sustainabledevelopment/wpcontent/uploads/2015/08/Factsheet_Summit.pdf.

lxxii. UN women, (2018). Mango farmers in Kenya get access to new technology to counter post-harvest losses:https://www.un.org/africarenewal/news/mango-farmers-kenya-get-access-new-technology-counterpost-harvest-losses.

lxxiii. Warburton, R.D.H., \&Cioffi, D.F., (2014). Project management theory: deriving a project's cost and schedule for its network structure, Project Management Institute Research and Education Conference, PA: Project Management Institute. https://www.pmi.org/learning/library/updating-project-management-theory-1917.

lxxiv. Westland, J. (2008). The Project Management Life Cycle: A Complete Step-By-Step Methodology for Initiating, Planning, Executing \& Closing a Project Successfully, SBN-13: 978-0749449377, ISBN-10: 0749449373. 